\title{
Cloning and Pharmacological Characterization of a Rat $\mu$ Opioid Receptor
}

\author{
Robert C. Thompson, Alfred Mansour, Huda Akil, \\ and Stanley J. Watson \\ Mental Health Research Institute \\ University of Michigan \\ Ann Arbor. Michigan 48109-0720
}

\section{Summary}

We have isolated a rat CDNA clone that displays $75 \%$ amino acid homology with the mouse $\delta$ and rat $\kappa$ opioid receptors. The CDNA (designated pRMuR-12) encodes a protein of 398 amino acids comprising, in part, seven hydrophobic domains similar to those described for other $G$ protein-linked receptors. Data from binding assays conducted with COS-1 cells transiently transfected with a CMV mammalian expression vector containing the full coding region of $p R M u R-12$ demonstrated $\mu$ receptor selectivity. In situ hybridization mRNA analysis revealed an mRNA distribution in rat brain that corresponds well to the distribution of binding sites labeled with $\mu$-selective ligands. Based upon these observations, we conclude that pRMuR-12 encodes a $\mu$ opioid receptor.

\section{Introduction}

The existence of multiple forms or subtypes of opioid receptors was first suggested by Martin and colleagues (Gilbert and Martin, 1976; Martin et al., 1976), using the chronic spinal dog preparation, and has since been supported by numerous behavioral, pharmacological, and receptor binding studies (Gillan and Kosterlitz, 1982; Wood, 1982; Goldstein and James, 1984; Herling and Woods, 1984; James and Goldstein, 1984). Opioid receptors have been divided into at least three main classes: $\kappa, \delta$, and $\mu$. These receptors have unique pharmacological profiles, anatomical distributions, and functions in several species, including man (Wood, 1982; Simon, 1991; Lutz and Pfister, 1992; Mansour and Watson, 1993). Several pharmacological agents as well as various members of the three endogenous opioid peptide families (prodynorphin, proenkephalin, and proopiomelanocortin) have been shown to interact with these receptors in distinctive and well-described manners. $\kappa$ receptors have been shown to exist in diverse regions of the CNS; they are particularly enriched in the cortex, striatum, and hypothalamus (Mansour et al., 1987; Nock et al., 1988; Unterwald et al., 1991) and are thought to mediate many of the actions of the dynorphin peptide family in addition to those of benzomorphans. These actions include the modulation of drinking, water balance, food intake, gut motility, temperature control, and various endocrine functions (Morley and Levine, 1983; leander et al., 1985; lyengar et al., 1986; Manzanares et al., 1990). $\delta$ receptors are also found throughout the CNS, particularly in forebrain areas such as the striatum and cerebral cortex, and have been shown to bind enkephalin-like peptides (Mansour et al., 1988; Wood, 1988). $\delta$ receptors are also thought to modulate several hormonal systems and to mediate analgesia.

The $\mu$ receptors represent the third member of the opioid receptor family. These receptors bind morphinelike drugs and several endogenous opioid peptides, including $\beta$-endorphin (derived from proopiomelanocortin) and several members of both the enkephalin and the dynorphin opioid peptide families. These receptors have been localized in many regions of the CNS, including the striatum (striatal patches), thalamus, nucleus tractus solitarius, and spinal cord (Mansour et al., 1987; McLean et al., 1986; Temple and Zukin, 1987; Wood, 1988; Mansour and Watson, 1993). $\mu$ receptors appear to mediate the opiate phenomena classically associated with morphine and heroin administration, including analgesia, opiate dependence, cardiovascular and respiratory depression, and several neuroendocrine effects. Pasternak and co-workers (Pasternak and Snyder, 1975; Wolozin and Pasternak, 1981; Pasternak and Wood, 1986; Pasternak, 1993) and Rothman and co-workers (Rothman ct al., 1987) have suggested that $\mu$ receptors can be subdivided into two classes, $\mu 1$ and $\mu 2 . \mu 1$ receptors are thought to have high affinity for both morphine and enkephalins. In contrast, $\mu 2$ receptors selectively interact with morphine-like compounds and DAMGO ([D-Ala ${ }^{2}, \mathrm{~N}-\mathrm{MePhe}^{4}, \mathrm{Gly}$-ol $\left.)^{5}\right] \mathrm{en}-$ kephalin). These studies further suggest that $\mu 1$ and $\mu 2$ are functionally distinct: $\mu 1$ receptors, unlike $\mu 2$ receptors, apparently mediate analgesia but not respiratory depression or physical dependence (Pasternak, 1993).

Owing to the importance of opioid receptors in opioid pharmacology and physiology, many researchers have attempted to purify these proteins with the aim of ultimately describing the molecular sequence of these receptors. In one such attempt, Schofield reported the isolation of a protein (opioid-binding cell adhesion molecule) apparently involved with an opioid receptor (Schofield et al., 1989). This protein has been shown to be a member of the immunoglobulin superfamily of cell adhesion molecules but lacks transmembrane domains, a feature assumed necessary for signal transduction. Using an expression cloning strategy, Xie et al. (1992) detailed the isolation and pharmacological identification of a $G$ protein-coupled protein with opioid receptor binding activity. This protein demonstrated several key features of opioid receptors: opioid binding and stereospecificity; however, the affinity $\left(\mathrm{K}_{\mathrm{D}}\right)$ for pharmacologically relevant agents was low and not selective. The biochemical purification of the $\mu$ receptor proteins has been reported by several groups (Simon et al., 1975; Bidlack and Abood, 1980; Ruegg et al., 1980; Simonds et al., 1980; Cho et al., 1981, 1986; Howells et al., 1982; Chow and Zukin, 1983; Demoliou-Mason and Barnard, 1984; Maneckjee 
et al., 1985; Ueda et al., 1987). Many of these reports suggest that this protein is approximately $40-60 \mathrm{kd}$. Additionally, this receptor can be functionally coupled to $G$ proteins (Koski and Klee, 1981; Barchfeld and Medzihradsky, 1984; Hsia et al., 1984; Puttfarchen et al., 1988; Attali et al., 1989). However, the low abundance of the protein and its apparently high hydrophobicity have proved to be major stumbling blocks for the sequencing of sufficiently long peptide fragments necessary for the molecular cloning of this receptor.

Kieffer et al. (1992) and Evans et al. (1992) reported the isolation and pharmacological characterization of the first high affinity opioid receptor, the $\delta$ opioid receptor, using an expression cloning strategy. This receptor was shown to contain seven hydrophobic domains characteristic of membrane receptors known to transduce extracellular signals (e.g., ligand binding) via $G$ proteins to the intracellular environment. The cloned receptors exhibited high affinity and selectivity for $\delta$ opioid ligands, and Evans et al. (1992) showed that activation of their receptor with selective $\delta$ agonists could decrease CAMP levels in transfected COS cells. The mouse $\delta$ receptors were found to be highly homologous to several members of the $G$ proteincoupled receptor family, particularly the somatostatin receptors. The cloning of the mouse $\delta$ receptors facilitated the cloning of other members of the opioid receptor family. Recently, Yasuda and co-workers described the isolation of a mouse $\kappa$ receptor CDNA that had been isolated as a member of the related somatostatin receptor family (Yasuda et al., 1993). Independently, our laboratory, using DNA fragments homologous to the mouse $\delta$ opioid receptor and low stringency cDNA library screening, isolated and pharmacologically characterized a rat $\kappa$ receptor CDNA (Meng et al., 1993). The rat and mouse $\kappa$ receptors contain seven transmembrane domains and are negatively coupled to adenylate cyclase via $G$ proteins. This report describes the cloning and characterization of a homologous seven transmembrane domain protein whose pharmacological profile and mRNA localization suggest that it is a rat $\mu$ receptor.

\section{Results}

\section{Isolation and Characterization of Rat $\mu$ Receptor cDNA Clones}

Using random primed cDNA from rat olfactory bulb and oligonucleotide primers (based upon transmembrane domains III, V, VI, and VII of the mouse $\delta$ opioid receptor mRNA [Evans et al., 1992; Kieffer et al., 1992]), amplified fragments were generated by the polymerase chain reaction (PCR) and subcloned. One clone, p5A-1, contained a DNA sequence that was $74 \%$ homologous at the nucleic acid level to the mouse $\delta$ opioid receptor mRNA sequence between transmembrane regions III and VI. The p5A-1 sequence was also similar ( $59 \%$ homology at the nucleic acid level) to several species of somatostatin receptor mRNAs. A rat olfactory bulb
XZAPII cDNA library was plated and screened with the radiulabeled DNA insert from p5A-1. Twelve positive clones were obtained. Restriction mapping and Southern blot analysis were performed on rescued plasmid DNA. One clone, designated pRMuR-12, demonstrated a strong hybridization signal on Southern blots and contained a cDNA insert of approximately $2.0 \mathrm{~kb}$. Various restriction enzyme digestion fragment of $p R M u R$ 12 were subcloned into Bluescript and completely sequenced in both orientations. DNA sequence analysis revealed that $p R M U R-12$ contained a full open reading frame with $74 \%$ homology with the mouse $\delta$ and rat $\kappa$ opioid receptor proteins.

\section{DNA and Protein Structure Analysis}

An EcoRI-HindIII fragment isolated form pRMuR-12 was shown to contain the entire protein coding region of this CDNA and was used for all subsequent experiments. The complete DNA sequence contained an open reading frame encoding a protein of 398 amino acids comprising, in part, seven hydrophobic domains. GenBank data base searches using both the amino acid and the nucleic acid sequences revealed that the pRMuR-12 sequence was novel and highly homolo gous to the mouse $\delta$ opioid receptor $(74 \%$ similar and $59.5 \%$ identical at the amino acid level) and the somatostatin receptors $(60.5 \%$ similar and $39.5 \%$ identical at the amino acid level). As can be seen in Figure 1 , the regions of greatest homology were found in the hydrophobic domains, particularly domains I, II, III, VI, and VII. The regions of greatest divergence included the amino and carboxyl termini of the protein, the region surrounding and including hydrophobic domain IV, and the region between hydrophobic domains $V$ and $V I$. In addition to the seven hydrophobic domains classically associated with $G$ proteincoupled receptors, the open reading frame contains several other features of this receptor family, including potential $\mathrm{N}$-linked glycosylation sites (five at amino acids 9, 31, 38, 46, and 53), palmitoylation sites (two at amino acids 346 and 351), and three phosphorylation sites (protein kinase $C$ phosphorylation at amino acid 363, calcium/calmodulin-dependent kinase phosphorylation at amino acid 261, and CAMP-dependent protein kinase [protein kinase $A$ ] phosphorylation at amino acid 279).

\section{Transient Transfection of CMV-pRMuR DNA into COS-1 Cells}

Initial binding assays performed on COS-1 cells transfected with the pCMV-neo (a gift from Dr. Michael Uhler, University of Michigan) expression vector containing the full open reading frame of pRMuR-12 demonstrated the opioid nature of the encoded receptor. [ ${ }^{3} \mathrm{H}$ ]DAMGO bound with high affinity $\left(K_{D}=1.2 \mathrm{nM}\right)$, whereas the selective $\kappa$ agonist $\left[{ }^{3} \mathrm{H}\right] \mathrm{U} 69,593(\mathrm{D}-(5 \alpha$, $7 \alpha ; 8 \beta)-(+)-N$-methyl-N-[7-(1-pyrrolidinyl)-1-oxaspiro-(4,5) dec-8-yl]benzeneacetamide) and the selective $\delta$ agonist $\left.{ }^{3} \mathrm{H}\right] \mathrm{DPDPE}$ (cyclic (D-penicillamine ${ }^{2}$, D-penicillamine ${ }^{\text {) }}$ enkephalin) did not. To characterize this clone 


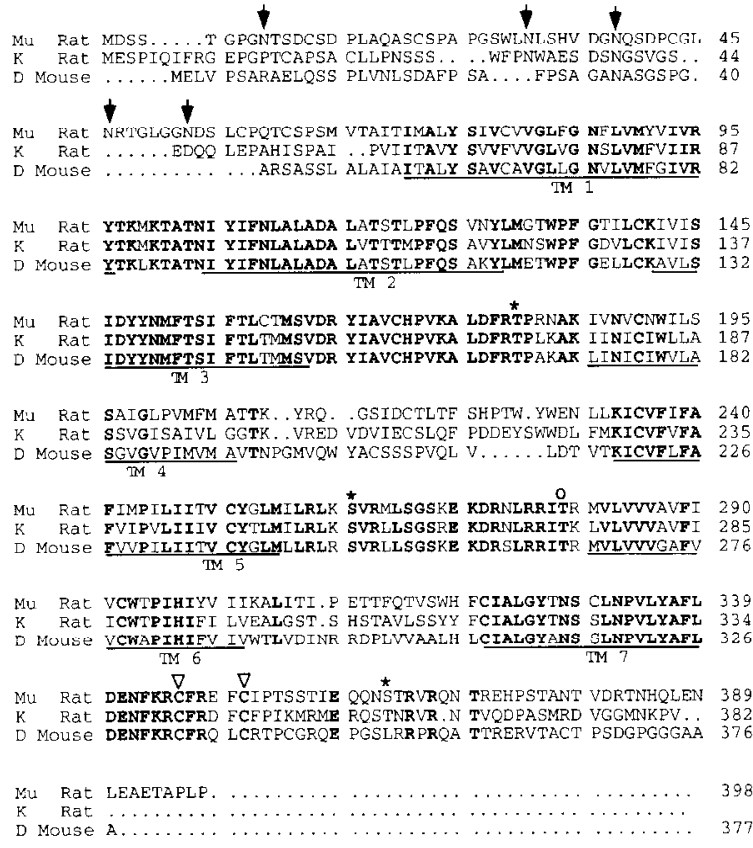

Figure 1. Amino Acids Comparison between the Rat $\mu$, Rat $\kappa$, and Mouse $\delta$ Opioid Receptor Sequences

The deduced amino acid sequence of the rat $\mu$ receptor ( $\mathrm{Mu}$ Rat) is compared with the rat $\kappa$ ( $K$ Rat) and mouse $\delta$ (D Mouse) receptors. Amino acids conserved in all three receptors are shown in bold. Putative transmembrane domains are underlined. The positions of potential $\mathrm{N}$-linked glycosylation sites are indicated by closed arrows. Consensus recognition sites for protein kinase C (asterisks), protein kinase A (open circle), and palmitoylation (open arrowheads) are also shown.

further, $\left[{ }^{3} \mathrm{H}\right]$ DAMGO $(1.6 \mathrm{nM})$ was used as a labeling ligand, and various $\mu-, \delta-$, and $\kappa$-selective ligands and nonselective ligands were tested in competition studies (Table 1). Several classic $\mu$-selective ligands had high affinities for the expressed receptor (morphine, $\mathrm{K}_{\mathrm{i}}=7.14 \mathrm{nM}$; levorphanol, $\left.\mathrm{K}_{\mathrm{i}}=0.78 \mathrm{nM}\right)$, whereas $\delta$ (DSLET [(D-Ser ${ }^{2}$, Leu $\left.{ }^{5}\right)$ enkephalin-Thr], $\mathrm{K}_{\mathrm{i}}=541.63 \mathrm{nM}$; DPDPE, $\left.K_{i}=4,100.00 \mathrm{nM}\right)$ and $\kappa(U 50,488[(\operatorname{trans})-3,4$ dichloro-N-methyl-N-[2-(1-pyrrolidinyl)cyclohexyl] benzene acetamide methanesulfonate], $K_{i}=1464.00 \mathrm{nM}$; U69,593, $\left.K_{i}=1910.00 \mathrm{nM}\right)$ ligands did not. DADLE (D-Ala-D-Leu-enkephalin; $K_{i}=6.56 \mathrm{nM}$ ) and the synthetic dynorphin (1-8) analog E2078 ( $\mathrm{N}$-methyl-Tyr ${ }^{1}$, $\mathrm{N}$ - $\alpha$-methyl-Arg7, $\mathrm{D}-\mathrm{Leu}^{8}$ ) dynorphin A-(1-8) ethylamide; $\mathrm{K}_{\mathrm{i}}=2.87 \mathrm{nM}$ ) were also potent in displacing [3H]DAMGO.

Several antagonists were also tested. Naloxone $\left(K_{i}=\right.$ $2.74 \mathrm{nM}$ ), naltrexone $\left(\mathrm{K}_{\mathrm{i}}=\mathbf{0} .36 \mathrm{nM}\right)$, CTAP (D-Pen-Cys Tyr-D-Trp-Arg-Thr-Pen-Thr-NH $\mathrm{NH}_{2} \mathrm{~K}_{\mathrm{i}}=0.21$ ), and nBNI (nor-binaltrophine $\mathrm{HCl} ; \mathrm{K}_{i}=3.90$ ) all displaced $\left[{ }^{3} \mathrm{H}\right] \mathrm{DAMGO}$ binding with high affinity. The expressed receptor also bound several nonselective opioid ligands such as $(-)$ bremazocine $\left(K_{i}=0.05 n M\right)$ and EKC (ethylketoclazocine; $\mathrm{K}_{\mathrm{i}}=1.28 \mathrm{nM}$ ) with high affinity. Furthermore, ligand binding to the transiently expressed receptor clone was stereospecific. (-)Brema-
Table 1. Pharmacological Profile of the Cloned Rat $\mu$ Receptor

\begin{tabular}{|c|c|}
\hline & $\mathrm{K}_{\mathrm{i}}(\mathrm{nM})$ \\
\hline \multicolumn{2}{|l|}{$\mu$ ligands } \\
\hline DAMGO & 1.57 \\
\hline Morphine & 7.14 \\
\hline Levorphanol & 0.78 \\
\hline \multicolumn{2}{|l|}{$\delta$ ligands } \\
\hline DADLE & 6.56 \\
\hline DPDPE & 4100.00 \\
\hline DSLET & 541.63 \\
\hline \multicolumn{2}{|l|}{$\kappa$ ligands } \\
\hline E2078 & 2.87 \\
\hline U50,488 & 1464.00 \\
\hline U69,593 & 1910.00 \\
\hline \multicolumn{2}{|c|}{ Nonselective ligands } \\
\hline EKC & 1.28 \\
\hline$(-)$ Bremazocine & 0.05 \\
\hline \multicolumn{2}{|l|}{ Enantiomers } \\
\hline (+)Bremazocine & $>5000.0$ \\
\hline Dextrorphan & $>5000.0$ \\
\hline \multicolumn{2}{|l|}{ Antagonists } \\
\hline CTAP & 0.21 \\
\hline Naloxone & 2.74 \\
\hline Naltrexone & 0.36 \\
\hline $\mathrm{nBNI}$ & 3.90 \\
\hline
\end{tabular}

Using [ ${ }^{3} \mathrm{H}$ DAMGO $(1.6 \mathrm{nM})$ as the labeling ligand, competition studies were performed on membrane preparations from COS-1 cells transiently transfected with pCMV-neo containing the full open reading frame of PRMuR-12. See text for description of ligands and abbreviations.

zocine and levorphanol bound with high affinity, but their enantiomers, (+)bremazocine and dextorphan, respectively, bound with low affinity.

Northern Blot Analysis of $\mu$ Receptor mRNA

Figure 2 show results from total RNA and poly(A) RNA from rat medulla/pons as well as poly(A) RNA from human SY5Y cells $(6 \mu \mathrm{g}$ for SY $5 Y$ and $10 \mu \mathrm{g}$ for medulla/ pons) electrophoresed on $16 \%$ formaldehyde-agarose $(1 \%)$ gels hybridized with cRNA probes complementary to p5A-1. Blots were hybridized and washed at high stringency. Lane 1 represents a short photographic exposure of the SY5Y mRNA lane (lane 2). Lanes 2 and 3 are from a $44 \mathrm{hr}$ autoradiogram detecting a single mRNA species in the rat medulla/pons mRNA sample and one prominent mRNA species in the human SY5Y cellular mRNA sample. Although less clear, analysis of total RNA from rat medulla/pons tissue (lane 4) identified a $\mu$ receptor RNA species that comigrated with the band seen in the poly(A) RNA (lane 3). These mRNAs are approximately 12,000-14,000 and $14,000-16,000$ nucleotides in length, respectively.

\section{Genomic Southern Blot Analysis}

Figure 3 show results from analysis of rat genomic DNA (20 $\mu \mathrm{g}$ per restriction enzyme digest) digested with restriction enzymes, electrophoresed on $0.8 \%$ agarose gels, and hybridized with random hexamer- 


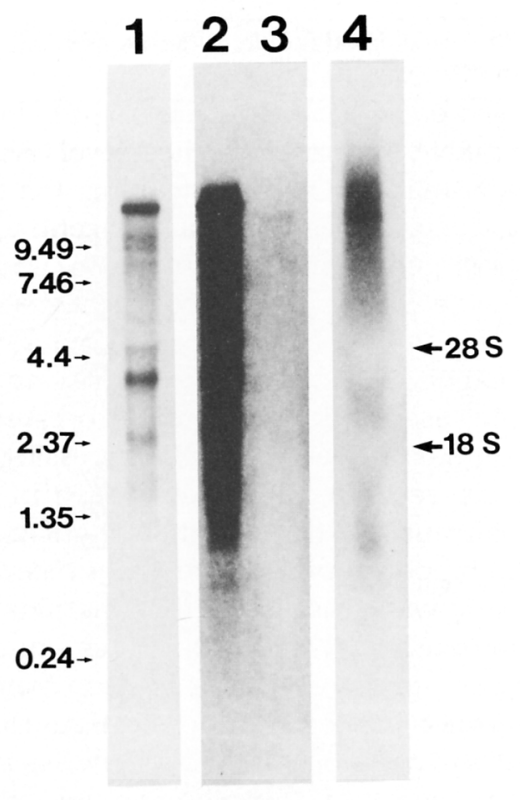

Figure 2. Northern Blot Analysis of Rat $\mu$ Receptor mRNA in Rat Medulla/Pons and SY5Y Cells

Poly(A) RNA (6 $\mu \mathrm{g}$ for SY5Y [lane 1 and 2] and $10 \mu \mathrm{g}$ for medulla/ pons [lane 3]) and total RNA (20 $\mathrm{hg}$ for medulla/pons [lane 4]) was electrophoresed on formaldehyde-agarose (1\%) gels, transferred to nylon membrane, and hybridized (overnight) at $60^{\circ} \mathrm{C}$ in $50 \%$ formamide, $1 \times$ HYB buffer. cRNA probes complementary to p5A-1 (see text) were used at approximately $2 \times 10^{6} \mathrm{cpms}$ of CRNA per $\mathrm{ml}$ of hybridization solution. Blots were washed in progressively decreasing SSC solutions (final concentrations of $0.1 \times \mathrm{SSC}, 0.5 \% \mathrm{SDS}$ ) at $72^{\circ} \mathrm{C}$ for $2 \mathrm{hr}$. Lane 1 represents a short photographic exposure of the SY $5 Y$ mRNA in lane 2. Lanes 2 and 3 represent exposures generated using two intensifying screens at $-70^{\circ} \mathrm{C}$ for $44 \mathrm{hr}$. Lane 4 represents an exposures using two intensifying screens at $-70^{\circ} \mathrm{C}$ for 7 days. Molecular weights were determined using an RNA ladder (BRL).

primed $2.0 \mathrm{~kb}$ cDNA from pMuR-12 as a probe under high stringency conditions. Several DNA bands were detected. Two bands were detected in the BamHI and Pstl lanes, consistent with the presence of these restriction endonuclease sites with in the CDNA sequence. Multiple hybridization-positive bands were detected in the HindIII and EcoRI lanes. There were no internal EcoRI sites and only one HindIII site found within the cDNA probe sequence. The presence of introns separating the $2.0 \mathrm{~kb}$ cDNA sequence into multiple exons would be consistent with the observed hybridization pattern in these two lanes. The presence of two hybridization-positive bands in the $\mathrm{BamHI}$ and Pstl lanes suggests that there is one $\mu$ receptor gene in the rat genome.

\section{Distribution of the $\mu$ Receptor mRNA}

In the olfactory bulb, from which the $\mu$ receptor $C D N A$ clone was derived, $\mu$ receptor $m R N A$ was localized to the internal granular and glomerular layers.

Neocortical areas such as the parietal and temporal cortices did not demonstrate the same receptor distribution, as might be expected from receptor binding

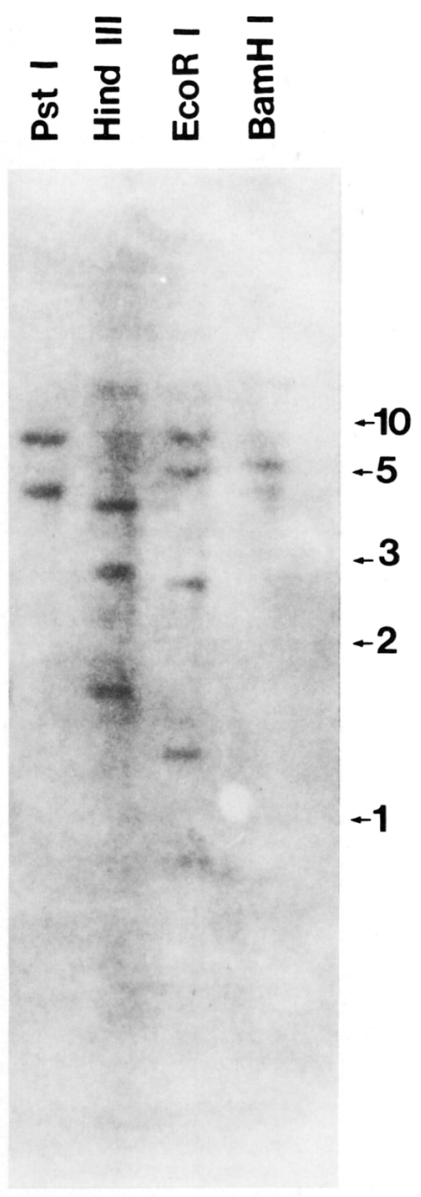

Figure 3. Cienomic Southern Biot of Rat $\mu$ Receptor

Rat genomic DNA (20 $\mu$ g per restriction enzyme digest) was digested with the indicated enzymes. Random hexamer priming of the full $2.0 \mathrm{~kb}$ cDNA from pRMuR-12 was used as a probe. Blots were washed in decreasing SSC solutions (final concentrations of $0.1 \times S S C, 0.5 \% \mathrm{SDS}$ ) at $60^{\circ} \mathrm{C}$ for $30 \mathrm{~min}$. Exposures were performed using two intensifying screens at $-70^{\circ} \mathrm{C}$ for $48 \mathrm{hr}$. Molecular weights were determined using an DNA ladder (BRL).

studies. A thin layer of cells expressing the $\mu$ receptor mRNA was observed in the deepest extents of layer $\mathrm{VI}$, and no cells were detectable in layers I and IV, as was demonstrated with receptor binding. Low levels of $\mu$ receptor $m R N A$ could be detected in the piriform and cingulate cortex and the deep layer of the entorhinal cortex. $\mu$ receptor mRNA was expressed at high levels in the striatal patches and the subcallosal streak ventral to the corpus callosum (Figure 4A). The $\mu$ striatal patches were most prominent in the rostral and lateral extents of the caudate-putamen and extended ventrally into the nucleus accumbens, where they were the most dense in the medial and ventral shell. Specific hybridization was also observed in the striatal matrix; however, expression levels were comparatively reduced. More laterally, the cells of the medial septum expressed high levels of $\mu$ receptor mRNA.

Scattered cells expressing high levels of $\mu$ receptor mRNA were seen in the bed nucleus stria terminalis 

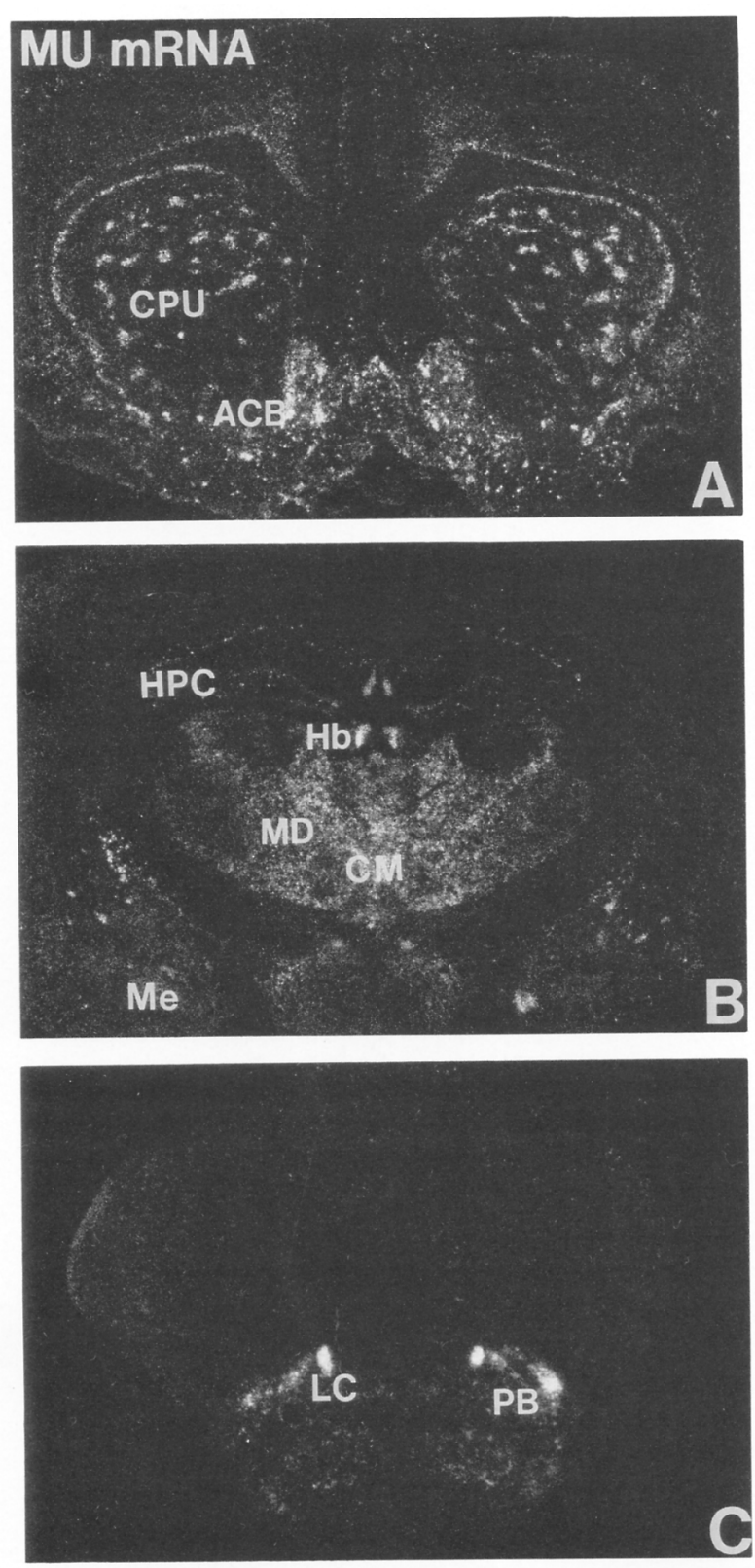

Figure 4. Dark-Field Autoradiograms Demonstrating the Distribution of $\mu$ Receptor mRNA at Three Levels of the Rat Brain (A), (B), and $(C)$ are sections through three levels of the brain. $\mu$ receptor mRNA is expressed in the striatal patches of the caudate-putamen (CPU) and nucleus accumbens (ACB), subcallosal streak, olfactory tubercle, several nuclei of the thalamus, including the medial habenula ( $\mathrm{Hb})$, the medial dorsal (MD), and the central (CM) nuclei, hippocampus (HPC), dentate gyrus, basolateral amygdala, medial amygdala (Me), locus ceruleus (LC) and parabrachial nucleus (PB).

and the medial preoptic area. In the medial preoptic area, the highest density of cells expressing $\mu$ receptor mRNA were observed in the anterior ventral division in the anterior medial preoptic and more posteriorly in the medial preoptic nucleus itself.

Scattered cells expressing $\mu$ receptor mRNA were also seen in the globus and ventral pallidum, regions demonstrating a low level of $\mu$ receptor binding and enkephalinergic projections.

Of the diencephalic structures expressing the $\mu$ receptor mRNA (Figure 4B), highest levels are observed in several thalamic nuclei, including the medial habenula, dorsomedial, ventrolateral, central, reuniens, and medial geniculate nuclei of the thalamus. By comparison, the vast majority of hypothalamic nuclei, including the paraventricular, periventricular, supraoptic, suprachiasmatic, ventromedial, and dorsomedial, did not appear to have cells that expressed $\mu$ opioid receptor mRNA. Scattered cells expressing moderate levels of $\mu$ receptor mRNA were seen in the lateral hypothalamus and the mammillary nuclei.

In the hippocampus (Figure $4 B$ ), $\mu$ receptor mRNA expression was observed in the pyramidal cell layer of the hippocampal formation and the granular cells of the dentate gyrus. As can be seen from the high magnification image of CA2 cells in Figure $5 \mathrm{~A}, \mu$ receptor mRNA expression was heterogeneous in the pyramidal cell layer; either not all cells expressed this gene or the cells expressed it at markedly reduced levels. It is unclear presently what the functional significance of this heterogeneity may be.

Several amygdaloid nuclei expressed the $\mu$ receptor mRNA, including the medial, basolateral, and cortical nuclei (Figure 4B). Levels were highest in the medial, posterior medial cortical amygdala, and intercalated nuclei of the basolateral amygdala.

In the midbrain (data not shown), $\mu$ receptor mRNA was observed in the ventral and lateral periaquaductal gray, a region known to subserve a role in pain and analgesia. $\mu$ receptor mRNA expression did extend to the pontine central gray. Low levels of $\mu$ receptor mRNA were also observed in scattered cells of the ventral tegmental area and substantia nigra, pars compacta.

Cells expressing $\mu$ receptor mRNA were also localized in the superior and inferior colliculi. Within the superior colliculus, $\mu$ receptor mRNA was primarily found in the large cells of the intermediate gray layer and in the inferior colliculus, cells of both the external cortex and the central nucleus express $\mu$ receptor mRNA.

The large cells of the red nucleus and the rostral, central, and lateral interpeduncular nuclei expressed $\mu$ receptor mRNA. As can be seen in Figure 5B, the highest density of cells expressing $\mu$ receptor $\mathrm{mRNA}$ were in the rostral division, with scattered cells in the central division. The levels of $\mu$ receptor mRNA expression in the lateral interpeduncular nucleus was low compared with other subdivisions.

Several brain stem nuclei expressed $\mu$ receptor mRNA. Highest levels were observed in the locus ceruleus and parabrachial nuclei (Figure 4C; Figure 5C). This distribution was consistent with the ability of $\mu$ opioid drugs to modulate norepinephrine release and to affect the levels of behavioral arousal. Scattered $\mu$-expressing cells were observed in the sensory and motor trigeminal, medial cerebellar, vestibular, and 

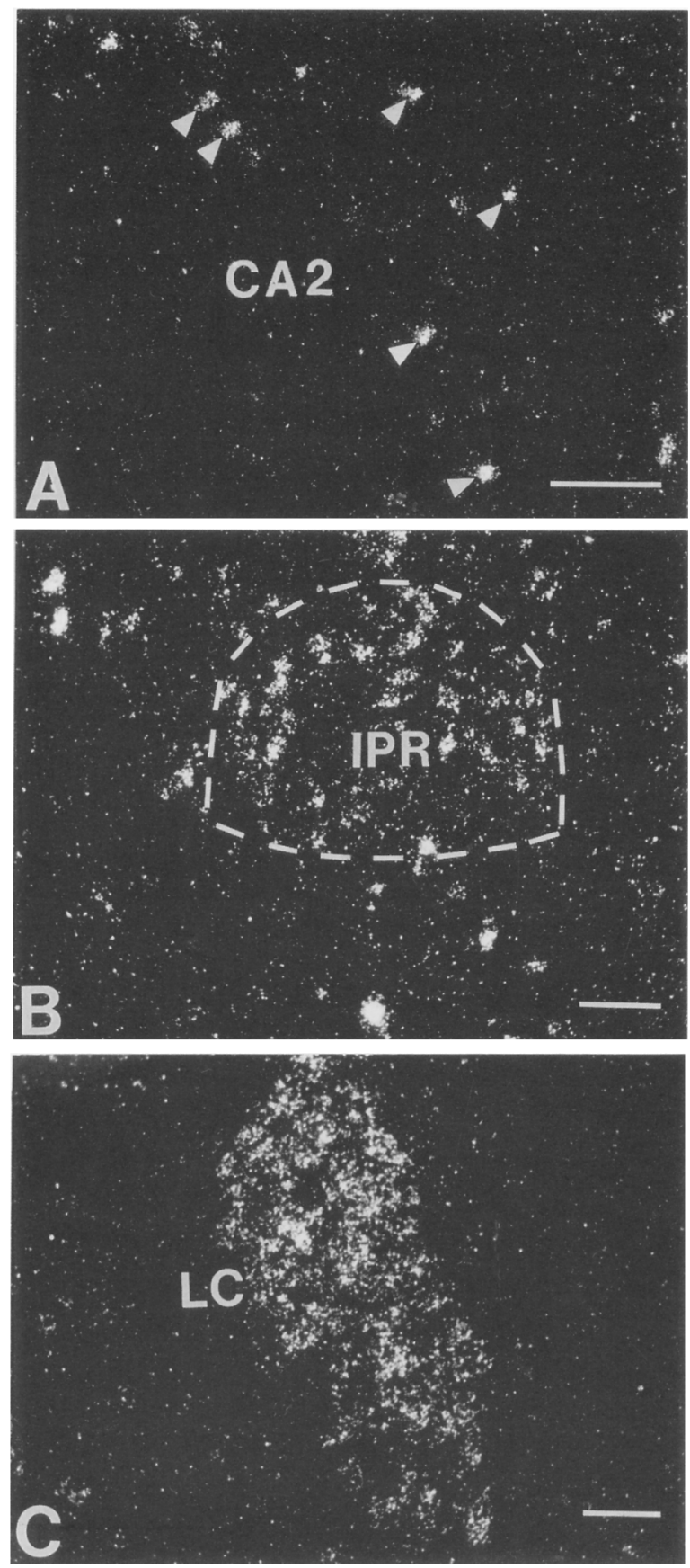

Figure 5. Dark-Field Photomicrographs of In Situ Hybridization Showing Cells Expressing $\mu$ Opioid Receptor mRNA in the CA2 Fieid of the Hippocampus, Interpeduncular Nucleus, and Locus Ceruleus

Note The high levels of expression in select cells of CA2 and in the rostral subdivision of the interpeduncular nucleus (IPR). LC, locus ceruleus. Bar, $100 \mu \mathrm{m}$.

facial nuclei, in the rostral olive, and in widely distributed cells of the recticular pontine. No $\mu$ receptor expression was found in the hypoglossal and cochlear nuclei.

Scattered cells of the raphe magnus and median raphe also expressed $\mu$ receptor $m R N A$, but the levels of expression were far higher in the median raphe. The nucleus of the solitary tract also demonstrated high levels of $\mu$ receptor $\mathrm{mRNA}$ and has been shown to be associated with cardiovascular, gustatory, and respiratory functions.

Moderate to high levels of $\mu$ receptor expression were also observed in cells of the cuneate, gracilis, and vagus nuclei (Figure 6). Figure 6A shows a low magnification in situ hybridization image of the $\mu$ receptor mRNA distribution in the medulla, with the gracilis, vagus, and cuneate nuclei highlighted in boxes. As can also be seen from Figure 6A, the large cells of the medulla reticular nucleus also expressed $\mu$ receptor mRNA.

In the spinal cord, the highest levels of opioid receptor binding were found in layers I and II, and only very low levels of $\mu$ receptor mRNA could be found in the spinal cord. However, as can be seen in the coronal section of spinal cord in which the dorsal root ganglia were also transected, high levels of $\mu$ receptor mRNA were found in the cells of the dorsal root gan. glia that project to layers I and II of the dorsal horn (Figure 7).

To control for potential cross-hybridization between this $\mu$ receptor cDNA sequence and other closely related receptors ( $\kappa$ and $\delta$ opioid receptors and somatostatin receptors), CRNA probes directed to different regions of the $\mathrm{PRMUR}-12$ protein (both to transmembrane domains $I I I-V I$ and to the 5 untranslated $/ \mathrm{N}$ terminus region) were used. In both cases, cRNA probes revealed indistinguishable mRNA distributions.

\section{Discussion}

The results of the present study demonstrate that we have cloned a novel member of the $G$ protein-coupled receptor family that can be identified as a rat $\mu$ opioid receptor. This conclusion is based on the following observations: First, the cloned receptor interacts with several classic opioid ligands, such as morphine, naltrexone, naloxone, levorphanol, and bremazocine, and their relative affinities are consistent with its opioid nature. Second, binding data show that the protein encoded by pRMuR-12 has a high affinity for the $\mu$ agonist DAMGO and the $\mu$ antagonist CTAP, whereas it has very low affinity for $\kappa$-selective $\cup 50,488$ and $\cup 69,593$ and $\delta$-selective DPDPE. Third, the receptor exhibits the predicted stereospecificity, recognizing (-)bremazocine and levorphanol with affinities several orders of magnitude higher than the affinities for their respective enantiomers, (1)bremazocine and dextrorphan. Fourth, the rank orders of agonist and antagonist binding are consistent with previously described in vivo pharmacology reported for $\mu$ receptors. Finally, the anatomical distribution of the mRNA coding for this receptor is in agreement with the distribution of $\mu$ receptor binding as defined with pharmacological ligands. Iaken together, these results provide compelling evidence that the present clone encodes a rat $\mu$ opioid receptor. 

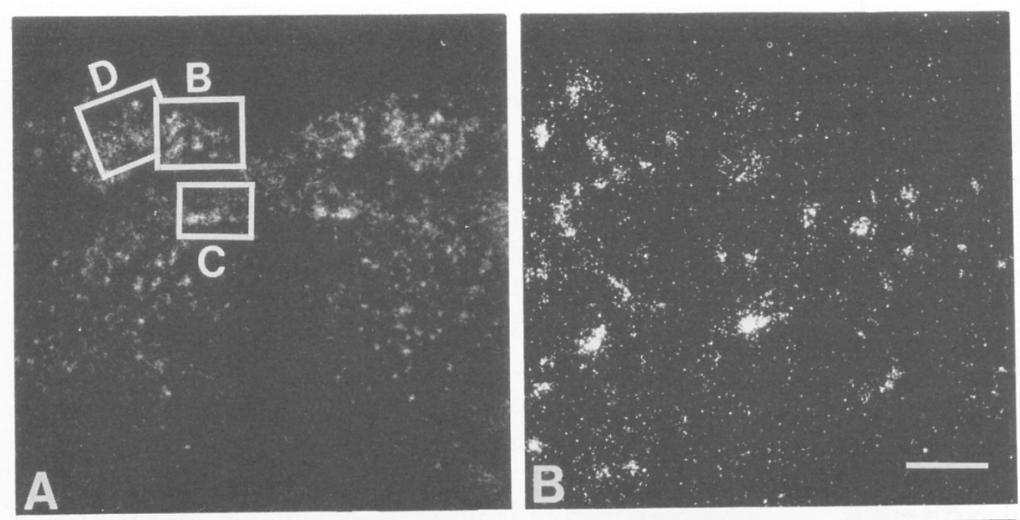

Figure 6. Dark-Field Photomicrographs of $\mu$ Receptor mRNA Expression Detected in the Caudal Rat Medulla Using In Situ Hybridization

(A) Low magnification image with regions of the gracilis (B), vagus (C), and cuneate (D) nuclei highlighted in boxes. High magnifications of the cells in each nucleus are provided in the corresponding panels. Note also $\mu$ receptor expression in the scattered cells of the medulla reticular formation, ventral and lateral to the vagus nucleus. Bar, $100 \mu \mathrm{m}$.
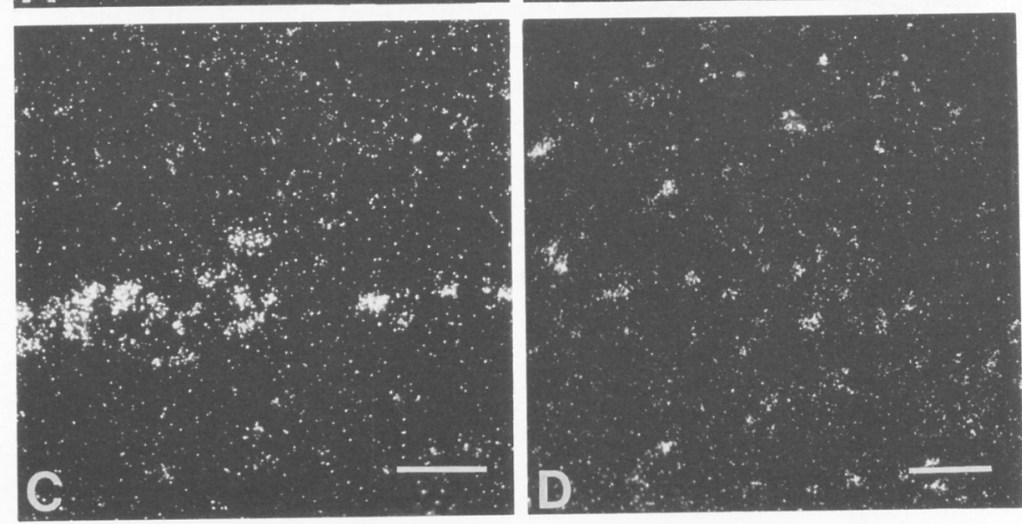

Several reports have suggested the presence of multiple receptor subtypes referred to as $\mu 1$ and $\mu 2$. $\mu 1$ receptor sites are defined as having high affinity (below $1 \mathrm{nM}$ ) for the $\mu$ and $\delta$ ligands DAMGO, morphine, DADLE, and DSLET and may be preferentially important in mediating analgesia. $\mu 2$ sites are defined by the ability of these same compounds to bind with lower affinity (1-10 $\mathrm{nM}$ ), with DAMGO having the highest affinity and morphine and DADLE having slightly lower affinities. If one accepts this classification, our cDNA clone appears to fit best with the $\mu 2$ subtype of $\mu$ receptors. Until a second $\mu$ receptor type is isolated and cloned, these assignments should remain tentative.

It was interesting to note that $\mathrm{nBNI}$, the $\mathrm{\kappa}$-selective antagonist, has a high affinity for the transiently expressed rat $\mu$ receptor. However, this should be viewed in relation to the affinity of $n B N I$ for the cloned $\kappa$ receptor. When the rat $\kappa$ receptor is transiently transfected into COS-1 cells, $\mathrm{nBNI}$ demonstrates approximately 11 -fold greater affinity for the rat $\kappa$ receptor $\left(K_{i}=0.26 \mathrm{nM}\right.$ for $\kappa$ versus $K_{i}=2.87 \mathrm{nM}$ for $\mu$ ) (Meng et al., 1993). These results compare well with nBNI's relative lack of selectivity in in vitro binding studies and point to the usefulness of comparing the pharmacology of opioid ligands in transiently transfected cell systems expressing an individual receptor.

Amino acid sequence comparisons of all three opioid receptors indicated that the $\mu$ receptor has a high degree of homology with the recently cloned mouse $\delta$ and rat $\kappa$ opioid receptors. The most homologous regions are the transmembrane domains and the intracellular loops. Putative transmembrane domains $I$, III, and VII are very similar among the three opioid receptors, followed by transmembrane domains $I, V$, and VI, with transmembrane IV being the least conserved. The high degree of homology among the intra-

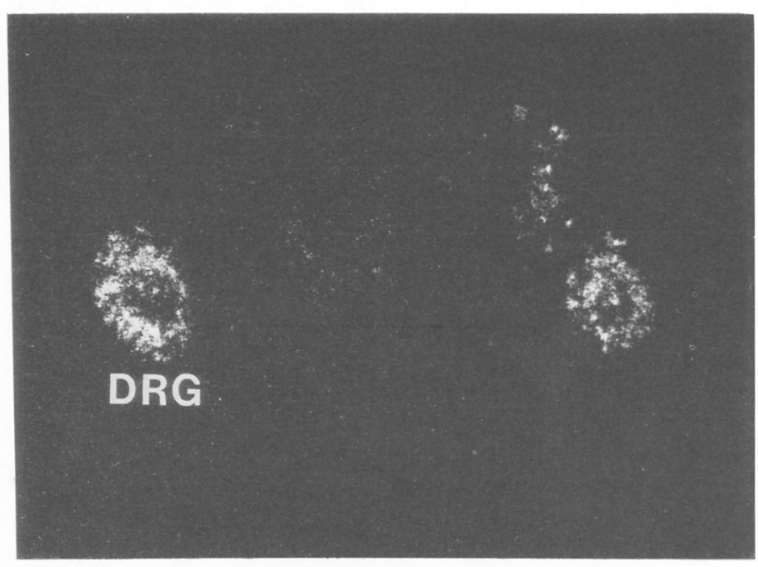

Figure 7. Dark-Field Autoradiogram of $\mu$ Recepto $r$ mRNA Expression in the Spinal Cord and Uorsal Root Ganglion Detected Using In Situ Hybridization

Thoracic spinal cord and its attached dorsal root ganglia were simultaneously dissected, frozen, sectioned, and subjected to in situ hybridization procedure (see Experimental Procedures). The spinal cord found between the two dorsal root ganglia in the figure demonstrates comparatively little $\mu$ receptor mRNA and is difficult to see at this film exposure. 
cellular loops of the $\delta, \kappa 1$, and $\mu$ receptors suggests that the receptors may share similar second messenger systems, since the intracellular loops are thought to be critical for the coupling of this receptor family to $G$ proteins (Clark et al., 1989). Additionally, many of the potential posttranslational features thought to be involved in the regulation of other receptors also appear to be conserved in opioid receptors. In addition to the general presence of $\mathrm{N}$-terminal glycosylation sites, $\mu$ receptor phosphorylation sites at amino acid 279 (protein kinase $A$ ) and amino acid 363 (protein kinase (C) and a palmitoylation site at amino acid 346 appear to be conserved across opioid receptor proteins. One of these sites, $\mathrm{Thr}^{279}$, in the $\mu$ receptor corresponds to a similar phosphorylation site in the $\beta$-adrenergic receptor. In the $\beta$-adrenergic receptor, this phosphorylation site is thought to be critical in agonist-induced desensitization mediated via $\mathrm{G}_{\mathrm{s}}$ activation and elevation of CAMP levels, whereby this site is phosphorylated, causing the dissocation of the receptor from the G protein (Clark et al., 1989). This site is completely conserved annong the three known classes of opioid receptors despite the fact that opioid receptors inhibit the generation of CAMP. Further studies will be needed to investigate the precise role, if any, of this conserved and putative phosphorylation site in opioid receptors.

Regions of divergence include the amino and carboxyl termini of the protein, as well as extracellular loops II and III. This sequence heterogeneity in these receptor domains is particularly striking and may be useful not only for discriminating opioid from nonopioid receptors (e.g., opioid from somatostatin), but also for discriminating opioid receptor types ( $\kappa$ from $\delta$ from $\mu$ ), as several of these regions are thought to be on the extracellular surface of the protein and may be involved in ligand selectivity. The notion that such extracellular domains may play an important role in determining ligand binding and ligand selectivity for peptide receptors was elegantly demonstrated in a series of studies on luteinizing hormone and folliclestimulating hormone receptors (Braun et al., 1991; Roche et al., 1992).

Rat $\mu$ receptor mRNA detected by Northern blot analysis is shown in Figure 2. Analysis of total RNA from many regions of the rat brain generated weak signals but indicated that the medulla/pons contained the greatest amount of $\mu$ receptor mRNA and was chosen for poly(A) mRNA purification. A single large molecular weight mRNA of approximately 12,000-14,000 nucleotides was detected in this poly(A) RNA from the medulla/pons. Human SY $5 Y$ cellular mRNA was also analyzed becausc of the presence of $\mu$ receptors in this cell line (as well as $\delta$ receptors). It appears that a prominent mRNA of approximately $14,000-16,000$ nucleotides is detected in this human cell line in addition to several other smaller mRNA species. It is unclear at this time whether these additional mRNAs are $\mu$ receptor forms or represent nonspecific hybridization, even though these blots were hybridized at high stringency. We are currently using DNA fragments from different regions of the rat $\mu$ receptor CDNA to determine whether these fragments identify the same mRNA species in this human cell line. It is interesting to note that in the $\delta$-expressing cell line NG108 five to six mRNA species were detected, although it appears that only two mRNAs are found in brain tissue.

Genomic Southern blot analysis of rat DNA using the full cDNA isolated from pRMuR-12 (approximately $2.0 \mathrm{~kb}$ ) indicates several interesting features of the structure of the rat $\mu$ receptor gene. tirst, the hybridization pattern in the BamHI and Pstl digests is consistant with the hypothesis that a single $\mu$ receptor gene exists in the rat genome. Second, there appears to be several introns separating the $2.0 \mathrm{~kb}$ CDNA. This is deduced from the multiple hybridization-positive bands in the EcoRl and Hindlll digest lanes seen in Figure 3. There are no EcoRI sites and only one HindIII site in the $2.0 \mathrm{~kb}$ cDNA fragment used as a hybridization probe, although several hybridization-positive bands are detected. Approximately, three to five bands are detected in the EcoRI lane, and five bands are detected in the HindIII lane, although one cannot rule out the possibility that some of these bands represent incomplete enzyme digests. In isolating cDNA clones encoding the rat $\mu$ receptor, one unusual cDNA clone appeared to contain an intron near the transmembrane IV location. Whether this CDNA clone contains an authentic intron or represents a cloning artifact is currently being evaluated. Interestingly, the mouse $\delta$ opioid receptor gene has an intron in a very similar location (Evans, personal communication). Isolation and characterization of rat genomic clones will address the complete structure of the $\mu$ receptor gene.

$\mu$ receptor mRNA is expressed in many regions and nuclei throughout the CNS. The high level of pRMuR12 mRNA in the olfactory bulb, striatal patches, subcallosal streak, thalamus, medial preoptic area, amygdala, interpeduncular, locus cerulus, parabrachial, cuneate, gracilis, and vagus nuclei, as well as in the nucleus of the solitary tract, is consistent with the known $\mu$-binding site distribution (Mansour et al., 1987; Mansour and Watson, 1993; McLean et al., 1986; Temple and Zukin; 1987) and the behavioral and pharmacological effects thought to be mediated by these receptors, including analgesia, respiration, cardiovascular effects, and hormonal regulation. The visualization of $\mu$ opioid receptor mRNA in the locus cerulus, ventral tegmental area, and substantia nigra, pars compacta is consistent with the ability of $\mu$ ligands to modulate presynaptic norepinephrine and dopamine release and may be critical in behavioral arousal and reward systems.

In situ hybridization results shown in Figure 7 suggest that while opioid receptor binding is localized predominantly in layers I and II of the spinal cord (Besse, 1991), $\mu$ receptor mRNA is found predominantly in the dorsal root ganglia. This suggests that the vast majority of $\mu$ receptors are likely transported from their site of synthesis in the dorsal root ganglia and are localized in presynaptic terminals in layers I and II 
of the spinal cord. This agrees well with lesion results (Besse et al., 1990), in which dorsal rhizotomy produced a $76 \%$ decrease in $\mu$ receptor binding in the spinal cord. Low $\mu$ receptor $m R N A$ expression is also found in the dorsal horns of the spinal cord itself, consistent with the presence of postsynaptic receptor sites.

During the preparation of this paper, Chen et al. (1993) reported the cloning and pharmacological characterization of a $\mu$ receptor also isolated from rat brain. The DNA sequence reported in this paper appears to be almost identical to the our $\mu$ receptor cDNA sequence, differing in the translation of only 1 amino acid residue (valine for isoleucine substitution in transmembrane region $\mathrm{V}$ ). These authors also report ago$n$ ist and antagonist binding profiles for their $\mu$ reccptor expressed in COS-7 cells. Many similarities are evident; however, they do not report binding for morphine. Additionally, these authors demonstrate that their $\mu$ receptor is functionally coupled to the inhibition of adenylate cyclase in the transiently transfected cells.

In summary, we have reported the isolation and characterization of a rat receptor CDNA whose pharmacological profile and anatomical distribution are consistent with the previously characterized $\mu$ receptor. RNA analysis demonstrated that the rat and possibly the human $\mu$ receptor $m$ RNAs are large molecular weight species. Genomic DNA analysis in the rat suggests that the rat $\mu$ receptor gene is found in a single copy with several introns. The availability of cloned opioid receptors will greatly enhance our understanding of the functions of these receptors in vivo, as well as provide for the systematic development of more selective agonists and antagonists. Developing ligands that can discriminate between various members of the opioid receptor family as well as between subclasses within an opioid receptor group could produce reagents that induce analgesia without many of the side effects (e.g., tolerance and dependence).

\section{Experimental Procedures}

\section{Isolation of Opioid Receptor Fragment}

Oligonucleotide primers complementary to regions encoding transmembrane domains III, V, VI, and VII of the mouse $\delta$ opioid receptor DNA sequence were designed and used in PCR. Primer 1 (TM 3), AAGAATTCTCAACATCATGAGCGTGGACCGCTAC; primer 2 (TM 5), AAGAATTCGGAACGTGGTGCCGATCCTCATCATC; primer 3 (TM 6), AAAAGCTTCCAGACGATGACGAAGATGTGGATGGG; primer 4 (TM 7), AAAAGCTITTAAGGGGAAGGTCGGGTAGGTCAGGCGGCAGCGCCACC. The PCR DNA template was first strand cDNA from rat olfactory bulb $m R$ NA generated with random hexamers using the Promega RiboClone cDNA Synthesis system. The PCR products were subcloned into a T-tailed vector system (Novagen) and sequenced using Sequenase (USB). Upon DNA sequencing, one amplified DNA fragment (432 bp) was shown to be $74 \%$ homologous to the NG108 $\delta$ opioid receptor mRNA from transmembrane regions III-VI. The DNA insert from this clone (designated p5A-1) was used for screening cDNA libraries and as a template to synthesize cRNA probes used for in situ hybridization.

Library Screening and Sequencing

$A$ rat olfactory bulb $\lambda$ ZAPII cDNA library was purchased and plated according to the manufacturer's recommendations (Stratagene). Approximately $3.2 \times 10^{6}$ CDNA clones were plated, and replicate nitrocellulose membranes were screened with a ${ }^{32} \mathrm{P}$-radiolabeled random-primed DNA insert from p5A-1 (432 bp). Prehybridization and hybridization conditions were $50 \%$ formamide, $1 \times$ hybridization buffer $\left(5 \times \mathrm{SSC}, 50 \mathrm{mM} \mathrm{KHPO}_{4}[\mathrm{pH}\right.$ 7.0], $1 \times$ Denhardt's solution, $0.1 \% \mathrm{PPO}_{4}, 0.1 \% \mathrm{SDS}, 200 \mu \mathrm{g} / \mathrm{ml}$ yeast $\mathrm{RNA}$ ) at $37^{\circ} \mathrm{C}$ for $16-18 \mathrm{hr}$. Twelve positive clones were obtained and plaque the purified. DNA inserts were rescued into plasmid using the M13 helper phage Exassist (Stratagene). Restriction mapping and Southern blot analysis were performed on rescued plasmid DNA. One clone, designated pRMuR-12, demonstrated a strong hybridization signal on Southern blot analysis and contained a cDNA insert of approximately $2.0 \mathrm{~kb}$. Various restriction enzyme digestion fragment of clone pRMUR12 were subcloned into Bluescript and completely sequenced in both orientations. An EcoRI-HindIII fragment was shown to contain the entire open reading frame of this CDNA. DNA sequence data were analyzed by the GCG package (Genetics Computer Group, 1991). The DNA sequence of pRMuR-12 has been submitted to GenBank under accession number L22455.

\section{Expression of Receptor and Binding Assay}

Initial binding assays performed on COS-1 cells transfected with the $\mathrm{PCMV}$-neo expression vector containing the full open reading frame of pRMuK-12 documented the opioid nature of the encoded receptor. For binding assays, $25 \mu \mathrm{g}$ of plasmid DNA was transfected into each $100 \mathrm{~mm}$ dish of COS-1 cells using the method of Chen and Okayama (1987). Receptor binding of the membrane preparation of the transfected cells was performed according to Goldstein and Naidu (1989). [ $\left.{ }^{3} \mathrm{H}\right] \mathrm{U} 69,593(58 \mathrm{Ci} /$ mmol; NEN), [ $\left.{ }^{3} \mathrm{H}\right] \mathrm{DAMGO}(55 \mathrm{Ci} / \mathrm{mmol} ; \mathrm{NEN})$, and [ $\left.{ }^{3} \mathrm{H}\right] \mathrm{DPDPE}$ $(34.3 \mathrm{Ci} / \mathrm{mmol} ; \mathrm{NEN})$ were used in the characterization of the receptor. Nonspecific binding was defined as the binding of radio ligand in the presence of $1 \mu \mathrm{M}$ levorphanol. ['H]DAMGO $(1.6 \mathrm{nM})$ was used to label the receptor in competition studies. All assays were conducted in $50 \mathrm{mM}$ Tris buffer $(\mathrm{pH}$ 7.4) at room temperature. Receptor binding results were analyzed with the LICAND program (Munson and Rodbard, 1980).

\section{Northern and Southern Blot Analyses}

RNA was isolated using standard guanidinium thiocyanate extractions with subsequent poly(A) RNA chromatography using Fastrack (Invitrogen) kits. Poly(A) RNA (6 $\mu \mathrm{g}$ for $5 \mathrm{Y} 5 \mathrm{Y}$ and $10 \mu \mathrm{g}$ for medulla/pons) was electrophoresed on $16 \%$ formaldehydeagarose $(1 \%)$ gels, transferred to nylon membrane (Nytran, Schleicher \& Schuell, Inc.), UV cross-linked, prehybridized ( $2 \mathrm{hr})$, and hybridized (overnight) at $60^{\circ} \mathrm{C}$ in $50 \%$ formamide, $1 \times$ HYB buffer (5x SSC, $50 \mathrm{mM} \mathrm{NaPO}{ }_{4}[\mathrm{pH} 7.4], 0.1 \% \mathrm{NaPPO}_{4}, 5 \times$ Denhardt's solution, $0.5 \% \mathrm{SDS}$ ). cRNA probes complementary to p5A-1 (see text) were generated using standard transcription methods and T7 RNA polymerase. Approximately, $2 \times 10^{6} \mathrm{rpms}$ of $\mathrm{cRNA}$ were used per $\mathrm{ml}$ of hybridization solution. Blots were washed in progressively decreasing SSC solutions, with final concentrations of $0.1 \times \mathrm{SSC}, 0.5 \% \mathrm{SDS}$, at $72^{\circ} \mathrm{C}$ for $2 \mathrm{hr}$. DNA was isolated from rat liver tissue, crushed on liquid $\mathrm{N} 2$, resuspended in proteinase $\mathrm{K}$ buffer ( $50 \mathrm{mM}$ Tris [pH 7.5], 0.5\% SDS, $5 \mathrm{mM}$ EDTA), digested for $3 \mathrm{hr}$, and gently extracted several times with phenol prior to RNAase treatment. These nucleic acid samples were reextracted with phenol-chloroform and ethanol precipitated. DNA was digested overnight with the indicated enzymes under manufacturer's recommended conditions. These digests were electrophoresed on $1 \times$ Tris borate EDTA, $1 \%$ agarose gels, acid nicked ( $30 \mathrm{~min}$, $0.25 \mathrm{M} \mathrm{HCl})$, denatured $(2 \times 30 \mathrm{~min} ; 0.5 \mathrm{M} \mathrm{NaOH}, 1.5 \mathrm{M} \mathrm{NaCl})$, neutralized $(2 \times 30 \mathrm{~min} ; 0.5 \mathrm{M}$ Tris $[\mathrm{pH}$ 7.4], $1.5 \mathrm{M} \mathrm{NaCl})$, and transferred to nylon membranes (Nytran, Schleicher \& Schuell, Inc.) in $10 \times$ SSC overnight. Blots were UV cross-linked and baked at $80^{\circ} \mathrm{C}$ under vacuum for $1.5 \mathrm{hr}$, prehybridized $(2 \mathrm{hr})$, and hybridized at $37^{\circ} \mathrm{C}$ in $50 \%$ formamide, $1 \times$ HYB buffer (see above) overnight. Random hexamer priming of the full $2.0 \mathrm{~kb}$ cDNA from pRMuR-12 was used as a probe at a concentration of $1.0 \times 10^{6}$ $\mathrm{cpm}$ per $\mathrm{ml}$ of hybridization buffer. Blots were washed in de- 
creasing SSC solutions (final concentrations of $0.1 \times$ SSC, $0.5 \%$ SDS) at $60^{\circ} \mathrm{C}$ for $30 \mathrm{~min}$.

\section{In Situ Hybridization}

Adult male Sprague-Dawley rats (20-25 g; Charles River) were sacrificed by decapitation. The brains were then dissected and frozen in liquid isopentane $\left(-30^{\circ} \mathrm{C}\right)$ for $30 \mathrm{~s}$ and transferred to dry ice. Frozen brains were stored at $-80^{\circ} \mathrm{C}$ until sectioning on a Bright cryostat $(15 \mu \mathrm{m})$. Brain sections were thaw mounted on precleaned and polylysine-subbed microscope slides and stored at $-80^{\circ} \mathrm{C}$.

Frozen brain sections were directly removed from storage at $-30^{\circ} \mathrm{C}$ and placed into $4 \%$ formaldehyde for $60 \mathrm{~min}\left(22^{\circ} \mathrm{C}\right)$ prior to processing for in situ hybridization (Mansour et al., 1990). Following three $5 \mathrm{~min}$ rinses in $2 \times \mathrm{SSC}(300 \mathrm{mM} \mathrm{NaCl}, 30 \mathrm{mM}$ sodium citrate $[\mathrm{pH} 7.2])$, sections were treated with proteinase $\mathrm{K}(1 \mu \mathrm{g} / \mathrm{ml}$ in $100 \mathrm{mM}$ Tris [pH 8.0], $50 \mathrm{mM}$ EDTA) for $10 \mathrm{~min}$ at $37^{\circ} \mathrm{C}$. Slides were then rinsed in water, followed by $0.1 \mathrm{M}$ triethanolamine $(\mathrm{pH} \mathrm{8.0)}$, and treated with a mixture of $0.1 \mathrm{M}$ triethanolamine $(\mathrm{pH} 8.0)$ and acetic anhydride $(400: 1, \mathrm{v} / \mathrm{v})$ with stirring for $10 \mathrm{~min}$. The sections were then rinsed in water, dehy. drated through graded alcohols, and allowed to air dry.

Rat brain sections were hybridized with $\left.{ }^{35} \mathrm{~S}\right] \mathrm{UTP}$ - and $\left[{ }^{35} \mathrm{~S}\right] \mathrm{CTP}$. labeled riboprobes generated to the PRMUR- 12 clone. The $\mu$ receptor CRNA was generated from a PCR fragment subcloned into pGEM4Z (designated p5A-1) and corresponds to transmembrane regions $|I I-V|$ of the receptor. As p5A-1 was produced using mouse $\delta$ opioid receptor mRNA primers, we also used a $759 \mathrm{bp}$ EcoRI-BamHI CDNA fragment derived from the 5 region of the pRMuR-12 cDNA clone. These two probes generated indistinguishable mRNA distributions. cRNA probe was diluted in hybridization buffer $75 \%$ formamide, $10 \%$ dextran sulfate, $3 \times$ SSC, $50 \mathrm{mM} \mathrm{Na}_{2} \mathrm{PO}_{4}$ [pH 7.4], $1 \times$ Denhardt's solution, $0.1 \mu \mathrm{g} / \mathrm{ml}$ yeast tRNA, $10 \mathrm{mM}$ dithiothreitol) to give a final concentration of $1 \times$ $10^{6}$ to $2 \times 10^{6} \mathrm{cpm} / 30 \mu$ l. Diluted probe was applied to coronal $(40 \mu \mathrm{I})$ and horizontal $(100 \mu \mathrm{l})$ sections. Glass coverslips were placed over brain sections to keep cRNA probes and hybridization buffer in contact with tissue.

Slides were then transferred to chambers containing $50 \%$ for mamide and hybridized at $55^{\circ} \mathrm{C}$, overnight. The slides were then rinsed in $2 \times$ SSC $(5 \mathrm{~min})$ and treated with RNAase A $(200 \mu \mathrm{g} /$ $\mathrm{ml}$ in $100 \mathrm{mM}$ Tris [ $\mathrm{pH} 8.0], 0.5 \mathrm{M} \mathrm{NaCl}$ ) for $60 \mathrm{~min}$ at $37^{\circ} \mathrm{C}$. Subsequently, the sections were rinsed in $2 \times$ SSC for $5 \mathrm{~min}$ $\left(22^{\circ} \mathrm{C}\right)$ and $0.1 \times \mathrm{SSC}$ for $60 \mathrm{~min}\left(65^{\circ} \mathrm{C}\right)$. Following the low salt wash, sections were rinsed in water, and dehydrated through graded alcohols, and air dried. Sections were apposed to Kodak XAR-5 X-ray film for 1-11 days or dipped in NTB2 film emulsion and developed 3-14 days later.

\section{Acknowledgments}

The authors would like to thank Dr. James Woods for providing the unlabeled opioid compounds used in this study and Drs. Bianca Ruzicka and Charles A. Fox for their critical reading and helpful discussion of this manuscript. This work was supported by NIDA Grant ROI DA02265 to H. A. and S. J. W., by Markey Grant (from the Lucille P. Markey Charitable Trust) \$88-46 to H. A. and S. J. W., and by Gut Center Grant P30-AM34933 to H. A. and S. J.W.

The costs of publication of this article were defrayed in part by the payment of page charges. This article must therefore be hereby marked "advertisement" in accordance with 18 USC Section 1734 solely to indicate this fact.

Received July 22, 1993; revised August 25, 1993.

\section{References}

Attali, B., Saya, D., and Vogel, Z. (1989). Kappa-opiate agonists inhibit adenylate cyclase and produce heterologous desensitization in rat spinal chord. J. Neurochem. 52, 360-369.

Barchfeld, C., and Medzihradsky, F. (1984). Receptor mediated stimulation of brain GTPase by opiates in normal and dependent rats. Biochem. Biophys. Res. Commun. 121, 611-648.

Besse, D., Lombard, M. C., Zajac, J. M., Roques, B. P., and Besson, J. M. (1990). Pre and postsynaptic distribution of $\mu, \delta$, and $\kappa$ opioid receptors in the superficial layers of the cervical dorsal horn of the rat spinal cord. Brain Res. 521, 15-22.

Beese, D., Lombard, M. C., and Besson, J. M. (1991). Autoradio graphic distribution of $\mu, \delta$, and $\kappa$ opioid binding sites in the superficial dorsal horn, over the rostrocaudal axis of the rat spinal cord. Brain Res. 548, 287-291.

Bidlack, J. M., and Abood, L. G. (1980). Solubilization of the opiate receptor. Life Sci. 27, 331-340.

Braun, T., Schofield, P. R., and Sprengel, R. (1991). Aminoterminal leucine-rich repeats in gonadotropin receptors determine hormone selectivity. EMBO J. 10, 1885-1890.

Chen, C., and Okayama, H. (1987). High efficiency transformation of mammalian cells by plasmid DNA. Mol. Cell. Biol. 7, 27452752.

Chen, Y., Mestek, A., Liu, J., Huriey, J. A., and Yu, L. (1993). Molecular cloning and functional expression of a $\mu$-opioid receptor from rat brain. Mol. Pharmacol. 44, 8-12.

Cho, T. M., Yamato, C., Cho, J. S., and Loh, H.H. (1981). Solubilization of membrane bound opiate receptors from rat brain. Life Sci. 28, 2651-2657.

Cho, T. M., Hasegawa, J.-I., Ge, B.-L., and Loh, H. H. (1986). Purification to apparent homogeneity of a $\mu$-type opioid receptor from rat brain. Proc. Natl. Acad. Sci. USA 83, 4138-4142.

Chow, T., and Zukin, R. S. (1983). Solubilization and preliminary characterization of mu and kappa opiate receptor subtypes from rat brain. Mol. Pharmacol. 24, 203-212.

Clark, R. B., Friedman, J., Dixon, R. A., and Strader, C. D. (1989). Identification of a specific site required for rapid heterologous desensitization of the beta-adrenergic receptor by CAMP-dependent protein kinase. Mol. Pharmacol. 36, 343-348.

Demoliou-Mason, C., and Barnard, E. A. (1984). Solubilization of high yield of opioid receptors retaining high-affinity delta, $\mathrm{mu}$ and kappa binding sites. FEBS Lett. 170, 378-382.

Evans, C. J., Keith, D. E., Morrison, H., Magendzo, K., and Edwards, R. H. (1992). Cloning of a delta opioid receptor by functional expression. Science 258, 1952-1955.

Genetics Computer Group (1991). Program Manual for the GCG Package (Madison, Wisconsin: University of Wisconsin Press). Gilbert, P. E., and Martin, W. R. (1976). The effects of morphineand nalorphine-like drugs in the nondependent, morphinedependent and cyclazocine-dependent chronic spinal dog. J. Pharmacol. Exp. Ther. 198, 66-82.

Gillan, M. G. C., and Kosterlitz, H. W. (1982). Spectrum of the $\mathrm{mu}$, delta, and kappa binding sites in homogenates of rat brain. Br. J. Pharmacol. 77, 461-469.

Goldstein, A., and James, I. F. (1984). Site-directed alkylation of multiple opioid receptors. II. Pharmacological selectivity. Mol. Pharmacol. 25, 343-348.

Goldstein, A., and Naidu, A. (1989). Multiple opioid receptors: ligand selectivity profiles and binding site signatures. Mol. Pharmacol. 36, 265-272.

Herling, S., and Woods, J. H. (1984). Discriminative stimulus effects of narcotics: evidence for multiple receptor-mediated actions. Life Sci. 28, 1571-1584.

Howells, R. D., Gioannini, T. L., Hilier, 1. M., and Simon, E. J. (1982). Solubilization and characterization of active binding sites from mammalian brain. J. Pharmacol. Exp. Ther. 222, 629-634.

Hsia, J. A., Moss, J., Hewlett, E. L., and Vaughan, M. (1984). ADP. ribosylation of adenylate cyclase by pertussis loxin. effecls on inhibitory agonist binding. J. Biol. Chem. 259, 1086-1090.

lyengar, S., Kim, H. S., and Wood, P. L. (1986). Effects of $\kappa$ opiate agonists on neurochemical and neuroendocrine indices: evidence for $\kappa$ receptor subtypes. Life Sci. 39, 637-644.

James, I. F., and Goldstein, A. (1984). Site-directed alkylation of 
multiple opioid receptors. I. Binding selectivity. Mol. Pharmacol. $25,337-342$.

Kieffer, B. L., Befort, K., Gaveriaux-Ruff, C., and Hirth, C. G. (1992). The $\delta$-opioid receptor: isolation of a CDNA by expression cloning and pharmacological characterization. Proc. Natl. Acad. Sci. USA $89,12048-12052$.

Koski, G., and Klee, W. (1981). Opiates inhibit adenylate cyclase by stimulating GTP hydrolysis. Proc. Natl. Acad. Sci. USA 78, 4185-4189.

Leander, J. D., Zerbr, R. L., and Hart, J. C. (1985). Diuresis and suppression of vasopressin by kappa opioids: comparison with mu and delta opioids and clonidine. J. Pharmacol. Exp. Ther. 234, 463-469.

Lutz, R. A., and Pfister, H. P. (1992). Opioid receptors and their pharmacological profiles. J. Receptor Res. 12, 267-286.

Maneckjee, R., Zukin, R. S., Archer, S., Michael, J., and OseiGyimah, P. (1985). Purification and characterization of the $\mu$ opiate receptor from rat brain using affinity chromatography. Proc. Natl. Acad. Sci. USA 82, 594-598.

Mansour, A., and Watson, S. J. (1993). Anatomical Distribution of Opioid Receptors in Mammalians: An Overview (Berlin: Springer-Verlag).

Mansour, A., Khachaturin, H., Lewis, M. E., Akil, H., and Watson S. J. (1987). Autoradiographic differentiation of mu, delta, and kappa opioid receptors in the rat forebrain and midbrain. J. Neuroscience $7,2445-2464$.

Mansour, A., Khachaturian, H., l ewis, M. F., Akil, H., and Watson, S. J. (1988). Anatomy of CNS opioid receptors. Trends Neurosci. 11, 308-314.

Manzanares, J., Lookingland, K. J., and Moore, K. E. (79y0). Kappa-opioid-receptor-mediated regulation of alpha-melanocyte-stimulating hormone secretion and tuberohypophyseal dopaminergic neuronal activity. Neuroendocrinology 52, 200205.

Martin, W. R., Eades, C. G., Thompson, J. A., I luppler, R. E., and Gilbert, P. E. (1976). The effects of morphine- and nalorphine-like drugs in the nondependent and morphine-dependent chronic spinal dog. J. Pharmacol. Exp. Ther. 197, 517-532.

McLean, S., Rothman, R. B., and Herkenham, M. (1986). Autoradiographic localization of $\mu$-and $\delta$-opiate receptors in the forebrain of the rat. Brain Res. 378, 49-60.

Meng, F., Xie, G.-X., Thompson, R. C., Mansour, A., Watson, S. J., and Akil, H. (1993). Cloning and pharmacological characterization of a rat kappa opioid receptor. Proc. Natl. Acad. Sci. USA, in press.

Morley, J. E., and Levine, A. S. (1983). Involvement of dynrophin and the $\kappa$ opioid receptor in feeding. Peptides 4, 797-800.

Munson, P. I., and Rodbard, D. (1980). LIGAND: a versatile computerized approach for characterization of ligand-binding systems. Anal. Biorhem. 107, 220-239.

Nock, B., Rajpara, A., O'Connor, L. H., and Cicero, T. J. (1988). Autoradiography of $\left[{ }^{3} \mathrm{H}\right] \mathrm{U}-69593$ binding sites in rat brain: evidence for kappa opioid receptor subtypes. tur. J. Pharmacol. 154, 27-34.

Pasternak, G. W. (1993). Pharmcological mechanisms of opinid analgesics. Clin. Neuropharmacol. 16, 1-18.

Pasternak, G. W., and Snyder, S. H. (1975). Identification of novel high affinity opiate receptor binding in rat brain. Nature 253, 563-565.

Pasternak, G. W., and Wood, P. L. (1986). Multiple $\mu$ receptors. Life Sci. 38, 1889-1898.

Puttfarchen, P. S., Werling, L. L., and Cox, B. M. (1988). Effects of chronic morphine exposure on opioid inhibition of adenylate cyclase in $7315 \mathrm{c}$ cell membranes: a useful model for the study of tolerance at $\mu$ opioid receptors. Mol. Pharmacol. 33, 520-527.

Roche, P. C., Ryan, R. J., and McCormick, D. J. (1992). Identification of hormone-binding regions of the luteinizing hormone/ human chorionic gonadotropin receptor using synthetic pep- tides. Endocrinology 131, 268-274.

Rothman, K. B., Jacobson, A. E., Kice, K. C., and Herkenham, M. (1987). Autoradiographic evidence for two classes of $\mu$ opioid binding sites in rat brain using [25]]FK33824. Peptides $8,1015-$ 1021.

Ruegg, U. T., Hiller, J. M., and Simon, E. J. (1980). Solubilization of an active opiate receptor from Bufo marimus. Eur. J. Pharmacol. $64,367-368$.

Schofield, P. R., McFarland, K. C., Hayflick, I. S., Wilcox, J. N., Cho, T. M., Roy, S., Lee, N. M., Loh, H. H., and Seeburg, P. H. (1989). Molecular characterization of a new immunoglobulin superfamily protein with potential roles in opioid binding and cell contact. EMBO f. 8, 489-495.

Simon, E. J. (1991). Opioid receptors and endogenous opioid peptides. Medicinal Res. Rev. 11, 357-374.

Simon, E. J., Hiller, J. M., and Edelman, I. (1975). Solubilization of a stereospecific opiate-macromolecular complex from rat brain. Science 190, 389-390.

Simonds, W. F., Koski, G., Streaty, R. A., Hjelmeland, L. M., and Klee, W. A. (1980). Solubilization of active opiate receptors. Proc. Natl. Acad. Sci. USA 77, 4623-4627.

Tempie, A., and Zukin, R. S. (1987). Neuroanatomical patterns of the $\mu, \delta$, and $\kappa$ opioid receptors of rat brain as determined by quantitative in vitro autoradiography. Proc. Natl. Acad. Sci. USA $84,4308-4312$.

Ueda, H., Harada, H., Misawa, H., Nozaki, M., and Takagi, H. (1987). Purified opioid $\mu$-receptor is of a different molerular size than $\delta$ - and $\kappa$-receptors. Neurosci. Lett. 75, 339--344.

Unterwald, E. M., Knapp, C., and Zukin, R. S. (1991). Neuroanatomical localization of kappa 1 and kappa 2 opioid receptors in rat and guinea pig brain. Brain Res. 562, 57-65.

Wolozin, B. L., and Pasternak, G. W. (1981). Classification of multiple morphine and enkephalin binding sites in the central nervous system. Proc. Natl. Acad. Sci. USA 78, 6181-6185.

Wood, P. L. (1982). Multiple opiate receptors: support for unique mu, delta, and kappa sites. Neuropharmacology 21, 487-497.

Wood, P. I (1988). The significance of multiple CNS opioid receptor types: a review of critical considerations relating to technical details and anatomy in the study of central opioid actions. Peptides 1, 49-55.

Xie, Y. B., Wang, H., and Segaloff, D. L. (1990). Extracellular domain of lutropin/choriogonadotropin receptor expressed in transfected cells binds choriogonadotropin with high affinity. J. Biol. Chem. 265, 21411-21414.

Xie, G.-X., Miyajimd, A., and Goldstein, A. (1992). Expression cloning of CDNA encoding a seven-helix receptor from human placenta with affinity for opioid ligands. Proc. Natl. Acad. Sci. USA 89, 4124-4128.

Yasuda, K., Raynor, K., Kong, H., Breder, C. D., Reisene, T., and Bell, G. I. (1993). Cloning and functional comparison of kappa and delta opioid receptors from mouse brain. Proc. Natl. Acad. Sci. USA, in press. 